\title{
Boomjuridischtijdschriften
}

\section{Regulering door middel van het privaatrecht}

\author{
prof.mr. M.W. Scheltema
}

Aanbevolen citeerwijze bij dit artikel

prof.mr. M.W. Scheltema, 'Regulering door middel van het privaatrecht', RegelMaat 2016-6, p. 410-424

\section{Inleiding}

De discussie over alternatieven voor (traditionele) overheidsregulering is niet nieuw. ${ }^{\mathbf{1}}$ In deze bijdrage komt echter een alternatief aan de orde dat als zodanig nog geen ruime belangstelling in de literatuur heeft genoten: regulering door middel van het privaatrecht. ${ }^{2}$ Los van de vraag wat hiermee nu precies wordt bedoeld, waar ik in de volgende paragraaf op inga, rijst de vraag waarom de overheid zou willen reguleren door middel van het privaatrecht. De huidige regeldruk wordt immers door velen al als knellend en belemmerend ervaren, bijvoorbeeld in de deeleconomie (Airbnb, Uber, Peerby). ${ }^{\mathbf{3}}$ Waarom zou daaraan nog een nieuwe vorm van regulering moeten worden toegevoegd? Bovendien bestaan een duidelijk kader en dito randvoorwaarden voor de traditionele wijze van reguleren door de overheid. Evident is dat een dergelijk kader en randvoorwaarden (nog) niet bestaan voor regulering door middel van het privaatrecht. Een dergelijke nieuwe vorm van regulering leidt daarmee tot (rechts)onzekerheid en wellicht ook tot tekorten in de rechtsbescherming (nu die bij de bevoegdheidsuitoefeningen gebaseerd op regulering door middel van het privaatrecht in de knel kan komen). Toch kunnen er voor de overheid (goede) redenen bestaan om naar dit instrument te grijpen. Zo kan, bijvoorbeeld in de thans groeiende deeleconomie of bij nieuwe technische ontwikkelingen, nog onduidelijk zijn hoe die precies op de klassieke manier kunnen/moeten worden gereguleerd, terwijl de overheid toch de behoefte voelt om publieke belangen op een adequate manier te borgen. ${ }^{4}$ Bovendien zijn Nederlandse overheden in verband met de toenemende internationalisering minder goed in staat om traditionele regulering te implementeren die werking heeft in de gehele internationale handel(sketens) en bijvoorbeeld voor internationaal opererende (internet)platforms. Ook is denkbaar dat de overheid niet voldoende expertise in huis heeft om bepaalde (technische) problemen aan te pakken en daarom de markt nodig heeft om regulering op een bepaald terrein vorm te geven. In dergelijke gevallen kan regulering door middel van het privaatrecht een welkom alternatief zijn. Daarom wordt die vorm van regulering in deze bijdrage aan een nader onderzoek onderworpen. Daarbij is van belang om naast de voordelen tevens te kijken naar mogelijke nadelen en naar de vraag hoe die nadelen zo goed mogelijk kunnen worden ondervangen (aan welke randvoorwaarden regulering door middel van het privaatrecht moet voldoen).

In deze bijdrage zal ik daarom eerst het begrip regulering door middel van het privaatrecht afbakenen en bezien of dit op zichzelf toelaatbaar is. Vervolgens zullen, ervan uitgaande dat deze vorm van regulering in beginsel toelaatbaar is, de voor- en nadelen ervan worden besproken. In dat verband wordt onderzocht welke randvoorwaarden moeten worden gesteld om die nadelen zo veel mogelijk te ondervangen. Er wordt in dat kader ook een praktijkvoorbeeld besproken: Airbnb.

\section{Afbakening van het onderwerp}

Het lijkt goed het onderwerp van deze bijdrage, regulering $\mathbf{5}$ door middel van het privaatrecht, af te bakenen. Het gaat bij deze vorm van regulering om door overheden opgestelde regels die bedoeld zijn om het algemeen belang te bevorderen en om meermaals te worden gebruikt. Anders dan voor traditionele regulering geldt, worden deze regels door middel van het privaatrecht (bijvoorbeeld via het eigendomsrecht, een overeenkomst of convenant) bindend gemaakt voor bepaalde partijen. Deze regels kunnen echter, zoals hierna wordt toegelicht, ook 
door private partijen opgestelde regels (zelf- en coregulering), waarin de overheid overigens een faciliterende rol kan spelen of zelfs kan deelnemen. ${ }^{6}$

Een klassiek voorbeeld van regulering door middel van het privaatrecht zijn erfpachtvoorwaarden. Daarin kunnen door de overheid in het kader van het algemeen belang wenselijk geachte regels, bijvoorbeeld omtrent toegelaten gebruik en een verplichting tot onderhoud van een op de grond staande woning, worden opgenomen. ${ }^{7}$ Ook andere vormen van gebruik van het eigendomsrecht van de overheid voor regulering door middel van het privaatrecht laten zich denken. Zo zal een overheid die eigenaar is van een natuurgebied op basis van haar eigendomsrecht regels kunnen stellen voor het vliegen met bijvoorbeeld drones in dat natuurgebied. $\mathbf{8}^{\mathbf{2}}$

Naast deze klassieke vorm treden thans ook andere vormen van regulering door middel van het privaatrecht meer op de voorgrond. Te denken valt aan afspraken die tussen bijvoorbeeld brancheverenigingen, koepelorganisaties of bepaalde (grote) partijen in een bepaalde branche en de (rijks)overheid worden gemaakt (in bijvoorbeeld een overeenkomst (convenant)) op het gebied van afvalstoffen, duurzaamheid, het handhaven van mensenrechten en andersoortige publieke belangen. ${ }^{9}$ Een voorbeeld is het recent in de kledingbranche gesloten convenant op het gebied van internationaal maatschappelijk verantwoord ondernemen. ${ }^{\mathbf{1 0}}$ Zulke afspraken kunnen een voorloper zijn van traditionele regulering of worden gemaakt onder het dreigement van (traditionele) regulering.

Deze vorm van regulering kan ook op een andere manier plaatsvinden. Denkbaar is dat een gemeente afspraken maakt met een grote marktpartij (in een overeenkomst/memorandum of understanding), welke afspraken (ook) gevolgen hebben voor burgers van die gemeente. Een voorbeeld dat hierbij in de buurt komt, is Airbnb. Daar kom ik in paragraaf 6 op terug. Meer in algemene zin kan (internet)technologie een dergelijke rol spelen. Zo kan een in software ingebouwde kopieer- of downloadbeveiliging voorkomen dat bepaalde illegale bestanden worden gekopieerd of gedownload. Als de relevante software dergelijke beveiligingen bevat, zou de overheid kunnen afzien van traditionele regulering die dergelijk illegaal kopiëren of downloaden verbiedt. ${ }^{11}$ Vaak zal het hier overigens gaan om zelfregulering, omdat de overheid weinig zicht heeft op hetgeen in software wel of niet wordt ingebouwd. ${ }^{\mathbf{1 2}}$ Alleen indien er duidelijke afspraken worden gemaakt tussen de softwareontwikkelaar en de overheid over welke technologie in software wordt ingebouwd en deze technologie gevolgen heeft voor derden (die daardoor bepaalde handelingen niet meer kunnen verrichten), zal sprake zijn van regulering door middel van het privaatrecht. Dergelijke afspraken hebben, voor zover mij bekend, (in Nederland) tot op heden echter nog geen grote vlucht genomen. Het zou kunnen dat deze in de verdere ontwikkeling van de deeleconomie, ${ }^{\mathbf{1 3}}$ waarvan ook Airbnb naast bijvoorbeeld Peerby en Uber deel uitmaakt, een grotere rol zullen gaan spelen. ${ }^{\mathbf{4}}$

Er wordt verder al langer nagedacht over de handhaving door middel van het privaatrecht. ${ }^{15}$ Dat is niet het onderwerp van deze bijdrage, nu het in beginsel niet gaat om regulering door middel van het privaatrecht. De grens tussen deze twee figuren is echter niet altijd scherp te trekken. Een tussenfiguur die zich in dat verband laat denken, is het geval waarin een toezichthouder in plaats van het maken van beleid waarmee hij zijn toezichtsbevoegdheden invult, kiest voor een overeenkomst met de gehele markt of een aantal (grote) marktpartijen. Het gaat dan niet om een oplossing die traditionele regulering vervangt of overbodig maakt, omdat anders beleidsregels zouden zijn gesteld door de toezichthouder, die de markt in beginsel niet binden. Toch is hier mijns inziens wel sprake van regulering door middel van het privaatrecht, omdat de regels die de toezichthouder anders in een beleidsregel zou hebben neergelegd nu bindend worden, doordat deze in een overeenkomst/convenant met de markt (of een aantal grote marktspelers) zijn vastgelegd. ${ }^{16}$

\section{Regulering door middel van het privaatrecht toelaatbaar?}

Men kan zich principieel afvragen of regulering door middel van het privaatrecht als zodanig wel toelaatbaar is en niet per definitie het publiekrecht doorkruist. ${ }^{17}$ Dat is mijns inziens niet in algemene zin het geval, voor zover de overheid binnen het bestaande (traditionele) reguleringslandschap de (beleids)vrijheid heeft om regels te stellen. ${ }^{\mathbf{1 8}}$ Regulering door middel van het privaatrecht is derhalve niet ten principale uitgesloten.

Wel kan zich een doorkruisingsprobleem voordoen als onderwerpen, mede vanuit een rechtsbeschermingsperspectief of vanwege de belangen van derden, alleen traditioneel mogen worden geregeld. Zo heeft de Afdeling beslist dat voorschriften die thuishoren in een bestemmingsplan niet in een overeenkomst kunnen worden geregeld. ${ }^{\mathbf{1 9}}$ Hetzelfde geldt voor het gebruik van openbare zaken conform hun bestemming. ${ }^{20}$ Daarnaast lijkt van doorkruising sprake te kunnen zijn indien dergelijke regulering de mededinging op ongeoorloofde wijze beperkt of in strijd is met (andere) publieke regelgeving, Europees recht en/of rechtstreeks 
dergelijke regulering onderwerpen tracht te regelen waarvoor een andere overheid regulerende bevoegdheid toekomt, zeker indien deze heeft aangekondigd daarvan gebruik te willen maken. In dergelijke gevallen stuit regulering door middel van het privaatrecht op problemen. Het gevolg kan zijn dat een contract of convenant waarin die regels zijn opgenomen, nietig is. ${ }^{\mathbf{2 2}}$

\section{Voordelen van regulering door middel van het privaatrecht}

Regulering door middel van het privaatrecht heeft een aantal evidente voordelen. ${ }^{\mathbf{2 3}}$ Deze vorm van regulering kan beter aansluiten bij eigen initiatieven in de markt omdat de markt zelf bij het opstellen ervan betrokken is. Dat kan de naleving van die regels ten goede komen. Deze regels kunnen immers beter aansluiten op het handelingsperspectief van de betrokkenen en daarmee een grotere bereidheid tot naleving opleveren, zeker als regulier overleg plaatsvindt tussen overheid en betrokkenen. ${ }^{24}$ Ook kan een nauwere band bestaan tussen het nemen van de beslissingen en het dragen van de gevolgen daarvan. ${ }^{25}$ Daarnaast worden de effecten van eenzijdige interventies door de overheid thans minder voorspelbaar geacht. ${ }^{\mathbf{2 6}}$

Bovendien kunnen deze regels flexibeler zijn (ze kunnen immers zodra partijen het erover eens zijn, worden gewijzigd) en daarbij sneller worden geïmplementeerd. Ook kan deze vorm van regulering het voordeel hebben dat een ontwikkeling, waarvan nog niet helemaal duidelijk is of en hoe die (traditioneel) moet worden gereguleerd, maar ten aanzien waarvan de overheid mogelijkheden wil bieden voor ontwikkeling en innovatie, vooruitlopend daarop door middel van het privaatrecht kan worden gereguleerd om het publieke belang te borgen. ${ }^{27}$ Voorbeeld is de deeleconomie, waarvan nog niet duidelijk is of, en zo ja, welke (traditioneel vormgegeven) regels daarvoor nodig zijn. ${ }^{28}$ Op dit moment is het daarom lastig om daarvoor al (effectieve) traditionele regelgeving in het leven te roepen. Regulering door middel van het privaatrecht kan in dergelijke situaties helpen bij het eventueel later vormgeven van traditionele regulering. Men kan immers zien welke (positieve en negatieve) effecten de via het privaatrecht geïmplementeerde regels hebben en deze zo nodig aanpassen, of in ieder geval meenemen wat wel en minder goed werkt. Daarnaast kan op deze manier ook beter gebruik worden gemaakt van de in de markt bestaande technische kennis.

Ten slotte kan deze vorm van regulering de enige mogelijkheid zijn in het internationale speelveld buiten (rechtstreeks werkende) verdragen. Buiten de landsgrenzen kan de Nederlandse overheid immers in beginsel niet reguleren. ${ }^{\mathbf{2 9}}$ Wil men regels implementeren die ook buiten de landsgrenzen hun werking hebben, dan lijkt implementatie door middel van privaatrechtelijke instrumenten (bijvoorbeeld overeenkomsten in handelsketens) de beste en ook minst omstreden mogelijkheid.

Verder kan een voordeel van het in de vorige paragraaf besproken toezichtsconvenant voor de toezichthouder zijn dat het niet alleen gaat om beleid waaraan de toezichthouder zelf is gebonden, maar om een overeenkomst/convenant waaraan ook de markt (of een aantal grote marktpartijen) zich heeft gecommitteerd. Dat is, zoals hiervoor is uiteengezet, relevant omdat dit betere naleving van de regels kan stimuleren. Bovendien worden de normen die de toezichthouder anders in een beleidsregel zou hebben neergelegd nu direct voor (een aantal van) de onder toezicht gestelden bindend. Deze regels zijn immers in een overeenkomst/convenant met de markt (of een aantal grote marktspelers) vastgelegd. Dit brengt mee dat (een deel van) de markt in beginsel kan worden gedwongen (via de burgerlijke rechter) om deze in de overeenkomst neergelegde regels na te leven.

\section{Nadelen van en randvoorwaarden voor deze vorm van regulering}

\subsection{Legitimiteit}

Regulering door middel van het privaatrecht heeft ook nadelen. Een in het oog springend nadeel is het ontbreken van democratische legitimatie en (in de meeste gevallen) een bij traditionele regelgeving (in beginsel) gebruikelijke afweging van alle betrokken belangen. ${ }^{\mathbf{3 0}}$ In de onderhandelingen met de markt of bepaalde commerciële partijen zullen immers niet (altijd) andere relevante spelers worden betrokken, zoals consumenten(organisaties) en andere belanghebbenden die de gevolgen van de regels ondervinden. Daarnaast bestaat het risico dat andere publieke belangen dan waarop de regels zien, zoals die van het milieu of duurzaamheid, aan de aandacht ontsnappen. Ook is denkbaar dat bepaalde afspraken voor grote ondernemingen goed werken, maar voor kleine onnodig belastend zijn. Dat geldt bijvoorbeeld als certificering (door onafhankelijke private partijen om de naleving van de regels te controleren) onderdeel is van de regulering door middel van het privaatrecht. Dergelijke certificering is kostbaar. De kosten daarvan vallen voor grote ondernemingen veelal makkelijker te dragen dan voor kleine. Deze kosten kunnen door grote ondernemingen veelal ook makkelijker worden afgewenteld. Als 
kleinere ondernemingen met minder klanten ligt dat (geheel) anders. Certificering zou derhalve markttoegang (ernstig) kunnen bemoeilijken voor kleinere ondernemingen en zou derhalve de facto een mededingingsverstorend effect kunnen hebben. Wanneer derhalve vooral zou worden gekeken naar de belangen van de grote ondernemingen, zou dat kunnen leiden tot (mededingings)problemen. Het is daarom van belang om ook bij regulering door middel van het privaatrecht een proces op te zetten waarin alle belanghebbenden worden betrokken. Vervolgens kunnen in dit proces de relevante belangen tegen elkaar worden afgewogen en kan daartussen een optimale verhouding worden gevonden. ${ }^{\mathbf{3}}$ Duidelijk is dat indien een dergelijke integrale belangenafweging niet wordt gemaakt, daardoor bepaalde (publieke) belangen in het gedrang kunnen komen. Dat geldt zeker als sprake is van zogenaamde 'regulatory capture', waarin de overheid zich te veel laat beïnvloeden door de belangen van de (markt)partijen waarmee zij over de regels in gesprek is. Daarnaast kan de rechtszekerheid in het gedrang komen als de regels onvoldoende kenbaar zijn (voor derden) $\mathbf{3 2}^{\mathbf{2}}$ of onduidelijk is voor wie zij precies gelden. Anders dan voor traditionele regulering geldt, waarvan dit proces van integrale belangenafweging in beginsel onderdeel uitmaakt, moet bij de vormgeving van regulering door middel van het privaatrecht derhalve een proces worden opgezet waarin de belanghebbenden worden betrokken. Er wordt op die manier een alternatief geboden voor de klassieke democratische legitimatie en er wordt (beter) inzicht gecreëerd in de beantwoording van de vraag voor wie de regels zijn bedoeld en wat de effecten ervan zijn voor de bedoelde belanghebbenden. Bovendien draagt een dergelijk proces bij aan de acceptatie bij de in dit proces betrokken belanghebbenden, en daarmee, waar relevant, aan de bereidheid tot naleving van de regulering door middel van het privaatrecht. Het opzetten van een dergelijk proces is mijns inziens dan ook randvoorwaardelijk voor regulering door middel van het privaatrecht. De overheid dient er derhalve op toe te zien dat dergelijke inspraak in voldoende mate wordt georganiseerd en zij dient die waar nodig ook te faciliteren. ${ }^{33}$

\subsection{Effectiviteit en proportionaliteit}

De vraag of regulering door middel van het privaatrecht proportioneel en effectief is, wordt in het algemeen niet onderzocht (bij wetgeving worden dergelijke impact assessments vaak wel gemaakt en wordt vaak ook voorzien in een evaluatie). Daarmee kan regulering door middel van het privaatrecht niet effectief zijn en onnodig belastend in verhouding tot de ermee nagestreefde publieke doelen. Het hiervoor gegeven voorbeeld van de verstoring van de mededinging illustreert dat. Hoewel door het hiervoor bedoelde betrekken van relevante belanghebbenden bij het opstellen van regulering door middel van het privaatrecht meer inzicht wordt verkregen in de effecten ervan, moet er daarnaast (meer objectief) worden onderzocht of deze vorm van regulering bijdraagt aan het bereiken van de ermee nagestreefde publieke doelen. De percepties van de belanghebbenden en de regulerende overheid daarover kunnen immers om allerlei redenen gekleurd zijn. Het voert binnen het bestek van deze bijdrage te ver om uit te werken op welke wijze dat effectiviteitsonderzoek zou kunnen plaatsvinden. Hier volsta ik met op te merken dat hiervoor een vergelijkbare benadering zou kunnen worden gekozen als voor het onderzoeken van de effectiviteit van zelf- en coregulering wordt voorgesteld. ${ }^{\mathbf{3 4}}$ Naast de hiervoor genoemde randvoorwaarde is derhalve van belang dat de effectiviteit (in de zin van het bereiken van de nagestreefde publieke doelen) van de regulering door middel van het privaatrecht wordt onderzocht. Er zal dus, net als bij (traditionele) regulering in beginsel gebeurt, vooraf moeten worden geanalyseerd of deze vorm van regulering kan bijdragen aan het bereiken van het ermee nagestreefde publieke doel (en bijvoorbeeld niet onnodig kostbaar is voor marktpartijen of andere belanghebbenden), en achteraf moeten worden geëvalueerd of dat ook daadwerkelijk het geval is geweest.

\subsection{Binding van relevante actoren}

Daarnaast brengt regulering door middel van het privaatrecht bij overeenkomsten met koepel- of brancheorganisaties mee dat deze overeenstemming niet alle (met het oog op het bereiken van de publieke doelstelling) te reguleren partijen hoeft te binden. Partijen die niet gebonden willen zijn, hoeven niet mee te doen. Er ontstaat dan het zogenaamde freeridersprobleem van bedrijven die wel profiteren van de inspanningen van de branche, omdat bijvoorbeeld consumenten er op grond van de in de branche geldende regulering door middel van het privaatrecht (ten onrechte) van uitgaan dat de hele branche zich daaraan houdt, maar zich daar zelf niet aan houden en daar ook niet aan bijdragen. ${ }^{35}$ Dit probleem kan deels worden ondervangen door een proces op te tuigen waarin alle relevante belanghebbenden participeren, maar ook dan zal er vaak een gedeelte van de markt resteren dat zich niet aan regulering door middel van het privaatrecht wil committeren. Als dat een relevant deel van de markt is, zal regulering door middel van het privaatrecht naar alle waarschijnlijkheid onvoldoende effectief zijn. Dan lijkt traditionele 
effectiviteit van regulering door middel van het privaatrecht via koepel-/brancheorganisaties is dan ook dat deze kunnen zorgen voor binding van een voor het bereiken van de publieke doelstelling voldoende groot deel van de markt.

\subsection{Inbedding in bestaand publiek regelgevingskader}

In een aantal gevallen zal voor een goede werking van het reguleringssysteem door middel van het privaatrecht bovendien informatie-uitwisseling met de overheid moeten plaatsvinden, bijvoorbeeld in het Airbnb-voorbeeld. Denkbaar is dat de overheid wil weten dat particulieren hun woning verhuren via Airbnb of informatie willen hebben over de (lengte van de) verhuur via Airbnb of daar gemelde klachten. ${ }^{\mathbf{3 6}}$ Dat kan problemen opleveren omdat die informatieuitwisseling niet steeds zonder meer mogelijk is zonder expliciete (traditioneel) wettelijke grondslag. ${ }^{37}$ Indien dergelijke informatie-uitwisseling niet mogelijk is of, zoals vaak het geval zal zijn, is beperkt, levert dat belemmeringen op die de effectiviteit van het private reguleringssysteem reduceren. Daarnaast speelt een rol of al bestaande (traditioneel) wettelijke normen zich verhouden met regulering door middel van het privaatrecht. Zo zullen bestaande open normen (bijvoorbeeld doelvoorschriften) daarmee kunnen worden ingevuld, maar dat is lastiger bij rule-based normen. ${ }^{3 \mathbf{8}}$ Ook het toezicht door publieke toezichthouders op de naleving van de regulering door middel van het privaatrecht zal daarop moeten zijn toegespitst, bijvoorbeeld in de zin van de aanwezige kennis, de mogelijkheid van het opleggen van sancties en van de beschikbare middelen. ${ }^{39}$ Niet ondenkbaar is dat private partijen worden betrokken bij het controleren van de naleving van de regulering door middel van het privaatrecht (bijvoorbeeld door middel van de hiervoor genoemde certificering). Dan hoeft de publieke toezichthouder minder intensief rechtstreeks toezicht te houden en zal zijn rol zich meer richten op het functioneren van de private controle. De publieke toezichthouder zal dan binnen het bestaande (traditionele) reguleringslandschap wel in staat/bevoegd moeten zijn om deze nieuwe rol te vervullen. Meer in algemene zin zal dus moeten worden bezien of het bestaande (traditionele) regulerings- en toezichtlandschap geschikt is voor regulering door middel van het privaatrecht.40 Dat is derhalve een verdere randvoorwaarde voor het gebruik van regulering door middel van het privaatrecht.

\subsection{Rechtsbescherming}

Vanuit rechtsbeschermingsperspectief zal regulering door middel van het privaatrecht er bovendien toe kunnen leiden dat de rechtsbescherming niet bij de bestuursrechter plaatsvindt. Anders dan bij op (traditionele) wetgeving gebaseerde bevoegdheidsuitoefeningen door de overheid het geval kan zijn, zal een bevoegdheidsuitoefening gebaseerd op regulering door middel van het privaatrecht in beginsel niet resulteren in een (voor bezwaar en beroep bij de bestuursrechter vatbaar) besluit. Dat kan echter anders zijn indien een publieke toezichthouder (op traditionele regelgeving gebaseerde) toezichtsbevoegdheden kan inzetten ter effectuering van de naleving van de regulering door middel van het privaatrecht. Die mogelijkheid kan bestaan indien regulering door middel van het privaatrecht een (in traditionele regelgeving opgenomen) open norm invult. Indien echter geen sprake is van een besluit behoeft dat niet zonder meer een probleem te zijn indien de rechtsbescherming bij de burgerlijke rechter plaatsvindt. In dat verband is van belang dat die ook thans al bevoegd is in verband met de toetsing van (de verbindendheid van) (traditioneel) publiekrechtelijke regulering en van bevoegdheidsuitoefeningen door de overheid die niet resulteren in een besluit. ${ }^{\mathbf{1 1}}$ De mogelijkheid van het afdwingen van naleving van regulering door middel van het privaatrecht bij de burgerlijke rechter hangt overigens wel af van de concreetheid van de regels. Zijn in regulering door middel van het privaatrecht enkel algemene beginselen vastgelegd, dan lijkt handhaving via de burgerlijke rechter in de praktijk lastig.

In het hiervoor genoemde voorbeeld van de deeleconomie kan de rechtsbescherming echter (deels) ook verschuiven naar private geschilbeslechtingssystemen van een forum als Airbnb. ${ }^{42}$ De ervaring leert, zoals hierna in paragraaf 6 verder wordt uitgewerkt, dat dergelijke geschilbeslechtingssystemen (in de verste verte) niet voldoen aan de eisen die aan een onafhankelijke rechtsgang bij de (bestuurs)rechter worden gesteld. Als daarna (in de praktijk) geen toetsing meer door een onafhankelijke (bestuurs- of burgerlijke) rechter mogelijk is, en dat lijkt in veel van dergelijke situaties het geval,43 zal een serieus gat ontstaan in de rechtsbescherming. Daarom lijkt, indien gebruik wordt gemaakt van regulering door middel van het privaatrecht, het stellen van minimumeisen aan de rechtsbescherming en private geschilbeslechtingsmechanismen onontbeerlijk.

In het kader van de rechtsbescherming is bovendien een probleem dat bij bepaalde besluiten gebaseerd op traditionele regelgeving ook derden belanghebbende zijn die bestuursrechtelijke 
wel door private partijen) worden genomen op grond van regulering door middel van het privaatrecht vaak niet (zonder meer) het geval zijn. ${ }^{44}$ Zo zou indien voor de vakantieverhuur van een woning een vergunningstelsel zou gelden, ook voor omwonenden en, waar toepasselijk, voor de vereniging van eigenaren als derde-belanghebbende, bestuursrechtelijke rechtsbescherming openstaan. 45 Wanneer enkel Airbnb toetst of aan de voorwaarden voor vakantieverhuur is voldaan, bestaat die rechtsbescherming voor derden niet ${ }^{\mathbf{6}} \mathrm{en}$ is in de huidige situatie voor deze derde-belanghebbenden in het geheel geen geschilbeslechting mogelijk indien zij het niet eens zijn met de beslissing van Airbnb om een woning voor vakantieverhuur toe te laten op de site. $\mathbf{4 7}$ Regulering door middel van het privaatrecht kan dus leiden tot (ernstige) tekorten in de rechtsbescherming. Deels kan dat probleem worden ondervangen doordat de overheid (al dan niet met informatie die, waar mogelijk, is verkregen van de private partij) zelf tot handhaving overgaat of dat weigert. Dan zal immers (in het algemeen) wel sprake zijn van een besluit in de zin van de Algemene wet bestuursrecht (Awb) (waartegen of de eigenaar kan opkomen als wordt gehandhaafd, of de bedoelde derden indien zij om handhaving hebben gevraagd en deze wordt geweigerd). ${ }^{48}$

Het vorenstaande neemt niet weg dat voor regulering door middel van het privaatrecht randvoorwaardelijk is dat eventuele tekorten in de rechtsbescherming worden geadresseerd en in dat verband duidelijke eisen worden gesteld aan eventueel gebruikte private geschilbeslechtingsmechanismen. Zeker waar enkel een niet-transparant en ontoereikend privaat geschilbeslechtingsmechanisme openstaat (zoals voor Airbnb geldt), zal moeten worden voorzien in aanvullende vormen van rechtsbescherming, dan wel zal het private systeem zodanig moeten worden verbeterd dat het rechtsbeschermingsgat op een toereikende wijze wordt opgevuld (hetgeen in de praktijk uitermate lastig en weerbarstig kan zijn, zeker bij internationaal opererende private actoren). Zolang niet in toereikende rechtsbescherming is of wordt voorzien, lijkt regulering door middel van het privaatrecht kwestieus.

\section{Voorbeeld: Airbnb}

Een voorbeeld dat tot de verbeelding zal spreken, en dat hiervoor al enkele malen de revue is gepasseerd, is Airbnb, de populaire website voor vakantieverhuur van woningen via een internetplatform. ${ }^{49}$ Dit platform opereert wereldwijd en is vaak goedkoper dan traditionele hotels, terwijl men verblijft tussen andere lokale bewoners en (als het goed is) niet tussen toeristen..$^{\mathbf{0}}$ Daarnaast worden transactiekosten tussen private huurders en verhuurders door dergelijke platforms verminderd. ${ }^{\mathbf{5 1}}$ Airbnb is volgens haar contractvoorwaarden echter alleen verantwoordelijk voor de website waarmee huurder en verhuurder met elkaar in contact komen en voor het afhandelen van praktische zaken, zoals het vasthouden van de betaling totdat de huurder de sleutel van het appartement heeft ontvangen. ${ }^{\mathbf{5 2}}$ Mede als gevolg van druk vanuit de media heeft Airbnb inmiddels wel een gedeeltelijke verzekering voor de verhuurder en een set van veiligheidsregels ingevoerd. ${ }^{53}$ Verder dienen de huurder en verhuurder nadere afspraken te maken. Indien een geschil ontstaat tussen huurder en verhuurder en zij zelf niet tot een oplossing komen, kunnen zij gebruik maken van het 'online dispute resolution center', dat op grond van 'het beleid' van Airbnb een bindende oplossing geeft indien partijen zich tot dat center wenden. ${ }^{54}$ De uitkomst van de beslissingen in deze geschillen wordt niet gepubliceerd. Het is voor huurders en verhuurders dan ook lastig te voorzien welke beslissing zij kunnen verwachten. ${ }^{55}$ Dat zal in het algemeen het vertrouwen in een dergelijke vorm van geschillenoplossing en de bereidheid deze te gebruiken niet bevorderen. Hoewel in theorie de weg naar de (burgerlijke) rechter openstaat, zullen veel gebruikers van Airbnb daartoe in de praktijk niet overgaan omdat de kosten van een procedure vaak niet in verhouding tot de schade staan. ${ }^{\mathbf{6}}$

Platforms als Airbnb kunnen, zoals hiervoor is uiteengezet, worden gebruikt als een manier om regulering door middel van het privaatrecht vorm te geven. De gemeente Amsterdam is een voorloper op dat terrein en heeft met Airbnb afspraken gemaakt die dicht in de buurt komen van regulering door middel van het privaatrecht. ${ }^{57}$ De gemeente Amsterdam heeft met Airbnb een Memorandum of Understanding gesloten, waarin onder meer afspraken zijn gemaakt over het ondersteunen door Airbnb van de handhaving van de voorschriften van de gemeente (considerans onder D en art. 3, 4.2, 4.5 en 4.6) omtrent het aantal dagen dat de burgers van Amsterdam hun woning maximaal mogen verhuren (zestig dagen), welke woningen mogen worden verhuurd (niet in de sociale huursector), de instemming van de verenigingen van eigenaren met de verhuur, overlast en toeristenbelasting..$^{\mathbf{5 8}}$ Door middel van het Memorandum of Understanding worden derhalve regels in het leven geroepen die niet alleen - of niet zozeer gelden voor Airbnb, maar ook ten opzichte van derden (burgers) die via Airbnb woningen voor vakantieverhuur aanbieden.

Wel moet worden bedacht dat in het geval van Airbnb nog sprake is van ondersteuning van de handhaving door Amsterdam. De regels waarbij Airbnb de gemeente ondersteunt, zijn in 
dus geen sprake van echte regulering door middel van het privaatrecht, maar van handhaving door middel van het privaatrecht. Dat neemt niet weg dat dit model ook zou kunnen worden gebruikt indien dergelijke traditionele regelgeving (nog) ontbreekt of ter verdere invulling/uitwerking daarvan. Dan is daadwerkelijk sprake van regulering door middel van het privaatrecht. In het Airbnb-voorbeeld lijkt het een kleine stap naar het in de overeenkomst/memorandum of understanding bepalen dat Airbnb bijvoorbeeld burgers die hun huis al meer dan zestig dagen hebben verhuurd de mogelijkheid tot verdere verhuur via Airbnb in dat jaar onthoudt. Dan wordt het beleid van de gemeente op dat punt omgezet in de facto bindende regels.

Overigens biedt de deeleconomie, waarvan ook Airbnb onderdeel uitmaakt, meer in algemene zin een voorbeeld waarin de overheid nog niet klaar is om traditionele regulering vorm te geven en haar toevlucht zoekt tot afspraken met de markt. ${ }^{59}$ De vraag is overigens waarom Airbnb over zou willen gaan tot het opnemen/handhaven van dergelijke overheidsregels. De reden daarvoor kan zijn dat zij wereldwijd met vele verschillende lokale en nationale regels wordt geconfronteerd, die aanzienlijk uiteen kunnen lopen. ${ }^{\mathbf{6 0}}$ Het kan dus aantrekkelijk zijn om een wereldwijde standaard te ontwikkelen waarmee (althans de meeste) lokale en nationale overheden instemmen. Het voldoen aan allerlei uiteenlopende publieke regels is immers complex en kostbaar, vooral voor internationaal opererende platforms als Airbnb.

Daarmee kan een organisatie als Airbnb als een verlengstuk van de overheid gaan optreden en komt regulering door middel van het privaatrecht tot stand. Dat heeft echter, zoals besproken, een aantal nadelen die door het stellen van de in paragraaf 5 genoemde randvoorwaarden zo veel mogelijk kunnen worden ondervangen. Van deze randvoorwaarden noem ik in het bijzonder de noodzaak van toereikende rechtsbescherming en private geschilbeslechting. Het huidige systeem dat Airbnb hanteert, voldoet niet aan de normen die wij aan geschilbeslechting in verhoudingen met de overheid stellen. Als nu echter (door overheden gestelde) regels worden gehandhaafd door Airbnb en geschillen door middel van de door Airbnb aangeboden private geschilbeslechting worden beslecht, ontstaat een rechtsbeschermingsgat. De geschillenbeslechting die Airbnb thans aanbiedt, is onvoldoende (als de gemeente regulering door middel van het privaatrecht zou willen inzetten). De gemeente zal daarom, indien zij voor deze wijze van regulering kiest, niet alleen kunnen volstaan met het sturen op de normen zelf, maar zal ook moeten letten op de geschilbeslechting. ${ }^{\mathbf{6 1}}$ Een andere oplossing zou overigens kunnen zijn dat na of naast de geschilbeslechting door Airbnb in de praktijk nog een gang naar de overheidsrechter openstaat. Dat is in het huidige stelsel echter praktisch gezien niet aan de orde als Airbnb op grond van haar regels actie onderneemt jegens degenen die van haar platform gebruik maken.

Daarnaast is mij niet bekend dat de gemeente Amsterdam bij het sluiten van het Memorandum of Understanding met Airbnb een proces heeft opgetuigd om (vertegenwoordigers van) belanghebbenden daarin te betrekken. Voor zover daadwerkelijk zou worden gereguleerd door middel van het privaatrecht zou dat wel moeten gebeuren. Denkbaar is bijvoorbeeld dat de gekozen vorm van regulering (waarvan ook certificering deel kan uitmaken) voor kleinere nationale internetplatforms te kostbaar is en de facto markttoegang belemmert. Als dan alleen met de grote platforms als Airbnb is gesproken, kan dat probleem buiten beeld raken. Bovendien is van belang of blijkt dat deze wijze van normering (beter) werkt (dan traditionele regulering). Ook de effectiviteit van de regulering door middel van het privaatrecht via Airbnb (met het oog op het bereiken van de daarmee beoogde publieke doelen) zal dus moeten worden gemonitord. In dat verband is bijvoorbeeld van belang of Airbnb de regels daadwerkelijk handhaaft en hoe dat kan worden gecontroleerd. Ten slotte zou deze vorm van regulering moeten passen in het bestaande traditionele regulerings- en toezichtlandschap. Zou die bijvoorbeeld niet toelaten dat (gevoelige) informatie over niet-naleving door particulieren van de regels door Airbnb aan de gemeente wordt doorgegeven, dan zal dat de effectiviteit van de regulering door middel van het privaatrecht kunnen verminderen. ${ }^{\mathbf{6 2}}$

\section{Afronding}

Het vorenstaande overziend kan worden gesteld dat regulering door middel van het privaatrecht interessante voordelen oplevert. Het kan in internationaal verband bovendien de enige manier zijn waarop overheden grip kunnen krijgen op internationale handelsketens of de (internationale) deeleconomie. Toch heeft deze vorm van regulering ook belangrijke nadelen, die niet alleen zijn gelegen in de geringe legitimiteit en mogelijke ineffectiviteit ervan, maar ook in gebrekkige rechtsbescherming. Dat neemt niet weg dat het gebruik van deze vorm van regulering wenselijk kan zijn, bijvoorbeeld omdat nog onvoldoende duidelijk is hoe traditionele regulering eruit zou moeten zien (bijvoorbeeld ten aanzien van de deeleconomie) of een markt nog onvoldoende is uitgekristalliseerd, terwijl de overheid toch bepaalde publieke belangen wil 
principale moet worden uitgesloten, maar deze vorm van regulering wel moet voldoen aan duidelijke randvoorwaarden. ${ }^{\mathbf{6 3}}$ Hiervoor is uiteengezet dat die randvoorwaarden samenhangen met (1) het opzetten van een proces waarin alle relevante belanghebbenden bij de vormgeving van regulering door middel van het privaatrecht worden betrokken, (2) (het onderzoeken van) de effectiviteit van deze vorm van regulering, (3) (indien toepasselijk) betrokkenheid van een voldoende groot deel van de relevante markt, (4) het passen van deze regulering in het al bestaande (traditionele) regulerings- en toezichtlandschap en (5) toereikende rechtsbescherming en, waar toepasselijk, (private) geschilbeslechting. Al met al is regulering door middel van het privaatrecht geen panacee voor het oplossen van allerhande problemen van (traditionele) regulering. Het vorenstaande neemt echter niet weg dat dit een interessante optie kan zijn indien aan de hiervoor besproken randvoorwaarden is voldaan.

\section{Noten}

1 Zie bijv. B. Dorbeck-Jung \& M. Oude Vrielink-van Heffen, 'Op weg naar bruikbare overheidsregulering?', Recht der Werkelijkheid 2006, p. 9-18. Deze bijdrage staat in het themanummer 'Over de waarde van alternatieve wetgevingsconcepten en alternatieven voor overheidsregulering', met daarin allerhande beschouwingen over alternatieven voor overheidsregulering en de gevolgen van de keuze voor andere reguleringssystemen. Zie voorts meer recent F.J. van Ommeren, 'Wetgevingsbeleid: remedies en instrumenten', in: S.E. Zijlstra (red.), Wetgeven. Handboek voor de centrale en decentrale overheid, Deventer: Kluwer 2012, p. 203 e.v.

2 Opvallend is in dat verband dat dit fenomeen ook in de Kamerbrief van 6 juli 2016, 'Werken aan toekomstbestendige wetgeving' (kenmerk DGBI-R\&I/16098216), niet (expliciet) wordt genoemd.

3 Vgl. Kamerstukken II 2015/16, 33009, 12, p. 5 en 6; Kamerbrief 6 juli 2016, p. 1-4, 8 en 12-14 (waarbij ook belemmeringen voor innovatie en groene groei worden genoemd).

4 Het gaat dan onder meer om het mededingingsrecht, databescherming, veiligheid, rechtszekerheid en de naleving van bestaande wet- en regelgeving. Zie Kamerstukken II 2015/16, 33009, 12, p. 2; Kamerbrief 6 juli 2016, p. 2, 4 en 14. Er moet uiteraard worden bezien welke belangen in het geding zijn en waar het belang van technische innovatie wordt begrensd door andere belangen, zoals een veiligheidsbelang. Zie Kamerbrief 6 juli 2016, p. 14.

5 De term regulering wordt in deze bijdrage dus in ruimere zin gebruikt dan de klassieke (indirect) democratisch gelegitimeerde regels van de overheid.

6 Zie voor vormen van transnationale zelf- en coregulering bijv. M.W. Scheltema, 'Transnationale private normen in het bestuursrecht', in: Hybride bestuursrecht (Preadviezen VAR Vereniging voor Bestuursrecht, deel 156), Den Haag: Boom juridisch 2016, p. 91-96. Deze vorm van regulering blijft in deze bijdrage dus verder buiten beschouwing.

7 Deze voorwaarden kunnen overigens ook onderdeel zijn van publieke regulering, bijv. als zij in een gemeentelijke verordening zijn opgenomen. Zie bijv. Van Ommeren 2012, p. 208-210; M. Scheltema \& M.W. Scheltema, Gemeenschappelijk recht, Deventer: Kluwer 2013, p. 316. Dat neemt echter niet weg dat deze voorwaarden door de erfpachter nog steeds (als een set algemene voorwaarden als bedoeld in art. 6:231 $\mathrm{BW}$ ) moeten worden aanvaard om hun gelding te hebben in de verhouding tussen de gemeente en deze burger. Zie Van Ommeren 2012, p. 208-210; Scheltema \& Scheltema 2013, p. 317.

8 Vgl. over drones de Kamerbrief van de staatssecretaris van Infrastructuur en Milieu van 11 maart 2016 (Kamerstukken II 2015/16, 31936, 326) en de aansluitende brieven met antwoorden op vragen (Aanhangsel Handelingen II 2015/16, 2399); Kamerbrief 6 juli 2016, p. 15, 16 en 17 (waar overigens vooral doelregelgeving als een oplossing wordt gezien).

9 Vgl. hieromtrent bijv. P.J. Huisman, De bevoegdhedenovereenkomst. De overeenkomst over het gebruik van een publiekrechtelijke bevoegdheid (diss. Amsterdam VU), Den Haag: Boom Juridische uitgevers 2012, p. 484 (met name de gevallen e en f) en 488-491. 
11 Zie daarover uitgebreid bijv. J.E.J. Prins, 'Normering, regulering en rechtshandhaving door technologie: over de implicaties van technoregulering voor het privaatrecht', WPNR 2011/6912.

12 Vgl. Prins 2011, par. 4, die constateert dat de overheid zich daarom niet geheel van haar verantwoordelijkheid kan ontdoen.

13 Zie over dit begrip bijv. V. Katz, 'Regulating the Sharing Economy', Berkeley Technology Law Journal (30) 2015, p. 1070 e.v., te vinden op

$<$ http://scholarship.law.berkeley.edu/cgi/viewcontent.cgi?article=2083\&context=btlj $>$. Zij ziet het verschil met meer traditionele dienstverlening via internet vooral in de mate waarin door het forum controle wordt uitgeoefend op transacties. Verder bestaan meer prikbordachtige toepassingen en sites die een echte rol vervullen als intermediair, zoals bij Airbnb. Zie over (de regulering van) de deeleconomie ook S. Ranchordás, 'Regels voor de digitale deeleconomie, oftewel “uber-regulering”, RegelMaat 2016, afl. 2, p. 102-116.

14 Ranchordás stelt aan de orde dat de overheid hier een keuze moet maken tussen publieke regulering en alternatieve vormen van regulering. Zie Ranchordás 2016, p. 113.

15 Zie bijv. Scheltema 2016, p. 137 e.v.

16 De facto kan een beleidsregel echter ook bindend zijn indien daarmee bijv. een open norm wordt ingevuld en de toezichthouder over publiekrechtelijke bevoegdheden beschikt om naleving van die open norm af te dwingen.

17 Of de doorkruisingsjurisprudentie van de Hoge Raad hier van toepassing is, is mede afhankelijk van de vraag of men de overeenkomst waarin de regels zijn vastgelegd als privaat- of publiekrechtelijk ziet. Ook in dat laatste geval kan de leer volgens Huisman echter wel analoog worden toegepast. Zie Huisman 2012, p. 507.

18 Zo ook Huisman 2012, p. 508 en 509.

19 ABRvS 11 februari 2004, Gst. 2004/193 m.nt. Teunissen (Tuingroep de Molukken). Zie voorts voor de vraag of een overeenkomst in de plaats kan komen van een voorwaardelijk voorschrift in een bestemmingsplan ABRvS 29 mei 2013, AB 2014/7; ABRvS 23 oktober 2013, AB 2014/8 m.nt. Nijmeijer. Zie ook P. van Buuren \& A.G.A. Nijmeijer, 'Bestemmingsplan en privaatrecht. Over voorwaardelijke verplichtingen en complementaire overeenkomsten', in: M.N. Boeve \& R. Uylenburg (red.), Kansen in het omgevingsrecht (Koeman-bundel), Groningen: Europa Law Publishing 2010, p. 427 e.v.

20 HR 7 april 2000, NJ 2000/652 m.nt. JH (Parkeerexploitatie/Amsterdam). Vgl. verder HR 16 mei 1986, $N J$ 1986/723 m.nt. MS (Heesch/Van de Akker).

21 Vgl. Huisman 2012, p. 501-507.

22 Zie over de gevolgen van doorkruising ook Huisman 2012, p. 509.

23 Vgl. voor vergelijkbare voordelen van regulering (mede) door private actoren Scheltema 2016, p. 96 en 97.

24 Vgl. Kamerbrief 6 juli 2016, p. 3.

$25 \mathrm{Vgl}$. in verband met private regulering I. Giesen, 'Alternatieve regelgeving in privaatrechtelijke verhoudingen'. In W.J. Witteveen, I. Giesen \& J.L. de Wijkerslooth, Alternatieve regelgeving. Handelingen Nederlandse Juristenvereniging 137e jaargang/2007-I, Deventer: Kluwer.2007, p. 87; Scheltema 2016, p. 96 en 97.

26 Kamerbrief 6 juli 2016, p. 1.

27 Vgl. Kamerstukken II 2015/16, 33009, 12, p. 1-3. Het kabinet lijkt overigens vooral te denken aan doelregulering, experimenteerbepalingen in (traditionele) regelgeving en het 'right to challenge'. Zie Kamerstukken II 2015/16, 33009, 12, p. 5; Kamerbrief 6 juli 2016, p. 5, 8 en 9.

28 Vgl. Ranchordás 2016, p. 115 en 116. 
29 Uiteraard is dat beeld enigszins ongenuanceerd, nu wel denkbaar is dat wetgeving met extraterritoriale werking wordt uitgevaardigd, zoals de UK Anti-Bribery Act, de UK Modern Slavery Act en de US Dodd-Frank Act. De effectiviteit daarvan is echter niet steeds even groot en bovendien is deze vorm van regulering omstreden als een vorm van inmenging in de soevereiniteit van andere landen. Dit neemt niet weg dat deze soms ook kan leiden tot veranderende inzichten van en in andere staten. Zie daarover bijv. in verband met anticorruptiewetgeving S.C. Kaczmarek \& A.L. Newman, 'The Long Arm of the Law: Extraterritoriality and the National Implementation of Foreign Bribery Legislation', International Organization (65) 2011, afl. 4, p. 745 e.v., te raadplegen via $<$ www.cambridge.org/core/journals/international-organization/article/the-long-arm-of-thelaw-extraterritoriality-and-the-national-implementation-of-foreign-briberylegislation/C7D17A57E38DDA6DB9ADF40F458FCF84>. Vgl. voorts in verband met de mogelijkheid voor staten in de VS om buiten hun grenzen te reguleren J.M. Schmitt, 'Constitutional Limitations on Extraterritorial State Power: State Regulation, Choice of Law and Slavery', te raadplegen via <http://papers.ssrn.com/sol3/papers.cfm?abstract_id=2312453>; M.D. Rosen, 'State Extraterritorial Powers Reconsidered', Notre Dame Law Review (85) 2010, afl. 3, p. 1033 e.v., te vinden op <http://scholarship.kentlaw.iit.edu/cgi/viewcontent.cgi? article $=3390 \&$ context $=$ fac $\_$schol $>$.

3o Vgl. uitgebreider voor transnationale zelf- en coregulering, waarbij eenzelfde probleem speelt, Scheltema 2016, p. 98, 116-120, 129 en 130.

$\mathbf{3 1}$ Of dat in de praktijk ook steeds gebeurt, laat ik in het midden.

32 Vgl. Huisman 2012, p. 544 en 545.

33 Denkbaar is ook om regulering door middel van het privaatrecht op landelijk niveau aan de Tweede Kamer en op lokaal/provinciaal niveau aan de gemeenteraad of provinciale staten ter kennisneming voor te leggen of zelfs ter goedkeuring. Vgl. Huisman 2012, p. 542 en 543. Ook dat zou de legitimiteit ervan vergroten, maar leidt er niet zonder meer toe dat ook inzicht ontstaat in de consequenties daarvan voor belanghebbenden.

34 Zie in verband met transnationale zelf- en coregulering Scheltema 2016, p. 122-130.

35 Zie ook Huisman 2012, p. 536-539.

36 In dat verband betoogt de gemeente Amsterdam dat ter voorkoming van overlast een meldplicht noodzakelijk is voor toeristische verhuur. De regering ziet echter geen aanleiding die in wetgeving te verankeren. Zie Kamerbrief 6 juli 2016, p. 13. Wel wordt bezien of platforms als Airbnb kunnen worden verplicht om informatie over verhuur aan gemeenten te verstrekken. Zie Kamerbrief 6 juli 2016, p. 13; Aanhangsel Handelingen II 2015/16, 2602.

37 Bijv. A.R. Neerhof, 'Alternatief bestuursrecht: normalisatie en conformiteitsbeoordeling in het publieke belang', in: Hybride bestuursrecht (Preadviezen VAR Vereniging voor Bestuursrecht, deel 156), Den Haag: Boom juridisch 2016, p. 221-226; Scheltema 2016, p. 151 en 152.

$38 \mathrm{Vgl}$. voor transnationale zelf- en coregulering Scheltema 2016, p. 146 en 147. Overigens is in verband met de invulling van open normen wel van belang dat de regels in de regulering door middel van het privaatrecht voldoende concreet zijn.

39 Vgl. Scheltema 2016, p. 146-152.

40 In dat verband moet er ook op worden gelet dat de hiervoor in par. 3 besproken doorkruisingsproblemen zich niet voordoen.

41 Vgl. Huisman 2012, p. 521-523.

42 Vgl. Huisman 2012, p. 523 en 524.

43 De beslissing van de private partij in het kader van de bestuursrechtelijke normering waarover een geschil ontstaat, bijv. dat een woning niet meer via Airbnb mag worden verhuurd, zal immers geen besluit in de zin van de Awb opleveren. 
$45 \mathrm{Vgl}$. Ranchordás 2016, p. 110.

46 Tenzij ook deze derden kunnen klagen in het private geschilbeslechtingsmechanisme. Dan resteert natuurlijk nog wel het punt van de ontoereikendheid van dit geschilbeslechtingsinstrument.

47 Behoudens wellicht (in theorie) een actie uit onrechtmatige daad jegens Airbnb bij de burgerlijke rechter, maar de kans dat daarvan in de praktijk gebruik gemaakt gaat worden, lijkt klein.

48 Dat geldt overigens niet voor de vereniging van eigenaren die nakoming vraagt van private regels (de splitsingsakte of het -reglement). Deze kan dat afdwingen via de burgerlijke rechter. Zie in algemene zin omtrent het vragen van nakoming van dergelijke overeenkomsten bij de burgerlijke rechter Huisman 2012, p. 513-516 en 519. Zie voorts over tekortkomingen in en ontbinding van dergelijke overeenkomsten Huisman 2012, p. 517 en 518.

49 Zie daarover bijv. Katz 2015, p. 1082 en 1083; V. Mak, 'Private Law Perspectives on Platform Services. Airbnb: Home Rentals between AYOR and NIMBY', Journal of European Consumer and Market Law (EuCML) 2016, afl. 1/2, p. 19-25. Dat enige regulering van Airbnb zelf nodig lijkt om uitwassen te voorkomen, wordt uiteengezet in Ranchordás 2016, p. 106, 107, 109 en 110. Zie hierover ook Kamerstukken II 2015/16, 33009, 12, p. 4 en 5; Kamerbrief 6 juli 2016, p. 12 en 13.

50 Zie daarover ook R. van Gestel, M. Loth \& V. Mak, 'Privaatrechtelijke rechtsvorming, regulering en wetenschap 0.13', NJB 2016, p. 1967.

51 Katz 2015, p. 1075.

52 Zie Van Gestel, Loth \& Mak 2016, p. 1967 en <www.airbnb.nl/terms>.

53 Van Gestel, Loth \& Mak 2016, p. 1967.

54 Van Gestel, Loth \& Mak 2016, p. 1967.

55 Van Gestel, Loth \& Mak 2016, p. 1968. Wel bestaat enig inzicht in de vraag wanneer teruggave van de huursom kan worden verwacht, zie

<https://www.airbnb.nl/home/cancellation_policies>.

56 Van Gestel, Loth \& Mak 2016, p. 1968.

57 Zie over de Amsterdamse benadering Ranchordás 2016, p. 114 en 115. Zie over de aanpak van Airbnb door de Europese Unie en buitenlandse gemeenten Ranchordás 2016, p. 112. Zie ook Kamerbrief 6 juli 2016, p. 13.

$\mathbf{5 8}$ Te raadplegen via <www.amsterdam.nl/wonen-leefomgeving/wonen/bijzonderesituaties/vakantieverhuur/>. Ook zijn daarin (art. 4.4 en 5.1) afspraken gemaakt over informatieuitwisseling tussen de gemeente en Airbnb ter bevordering van de handhaving van de gemeentelijke regels. Zie daarover ook Ranchordás 2016, p. 114 en 115.

59 Vgl. Ranchordás 2016, p. 115 en 116.

6o Vgl. Katz 2015, p. 1080 en 1081.

61 Er wordt voorgesteld hier in ieder geval geschilbeslechting door een (onafhankelijke derde) te laten plaatsvinden en ook de mogelijkheid te openen voor derden om te klagen. Zie Katz 2015, p. 1112.

62 De vraag is vervolgens wat rechtens is als de overheid onvoldoende let op de hiervoor besproken randvoorwaarden en toch reguleert door middel van het privaatrecht. Niet uit te sluiten valt dat dit onrechtmatig handelen jegens daardoor gedupeerde burgers zou kunnen opleveren of Airbnb zou kunnen worden verboden om deze regels nog langer te hanteren/handhaven, bijv. via de beperkende werking van de redelijkheid en billijkheid in de tussen de huurder/verhuurder en Airbnb bestaande contractuele verhouding. 
63 Vgl. voor transnationale zelf- en coregulering Scheltema 2016, p. 122 e.v.

(C) Boom juridisch 